\title{
Non-Tethered Organometallic Phosphonate Inhibitors for Lipase Inhibition: Positioning of the Metal Center in the Active Site of Cutinase
}

\author{
Cornelis A. Kruithof, ${ }^{[a]}$ Harmen P. Dijkstra, ${ }^{[a]}$ Martin Lutz, ${ }^{[b]}$ Anthony L. Spek, ${ }^{[b]}$ \\ Maarten R. Egmond, ${ }^{[c]}$ Robertus J. M. Klein Gebbink, ${ }^{*[a]}$ and Gerard van Koten*[a]
}

\author{
Dedicated to Jan Reedijk on the occasion of his 65th birthday["\#]
}

Keywords: Protein modifications / Inhibitors / Phosphonates / ECE-Pincer complexes / Hydrolases

Organometallic NCN-pincer complexes, bearing either a $p$ nitrophenyl phosphonate ester or a phosphonic acid group directly attached to the aromatic ring of the pincer complex, were synthesized. These compounds were tested as covalent inhibitors for the lipase cutinase. In a stoichiometric reaction of the NCN-pincer platinum phosphonate $p$-nitrophenyl ester 2 with cutinase, a $94 \%$ conversion to the protein-pincer metal complex hybrid was obtained in $48 \mathrm{~h}$. The NCN-pincer metal phosphonic acid derivatives $(3,4)$ appeared to be inactive as cutinase inhibitors. In contrast to our previous work which entails propyl tethered phosphonate esters connected to pincer metal complexes, the presented strategy allows positioning of metal complexes inside the active site of lipases. This opens up the possibility for fine-tuning the chemical environment (second coordination sphere) around a synthetic metal center inside the pocket of an enzyme for diagnostic and catalytic purposes.

(@ Wiley-VCH Verlag GmbH \& Co. KGaA, 69451 Weinheim, Germany, 2008)

\section{Introduction}

Phosphonates bearing at least one good leaving group (e.g. fluoride or $p$-nitrophenyl) are well-known for their powerful inhibition activity of serine hydrolases, a family of enzymes responsible for ester and amide hydrolysis in nature. ${ }^{[1-4]}$ Their inhibition efficiency originates from their structural properties, which closely mimic the first transition state of ester and amide, hydrolysis reactions (Figure 1). Upon covalent binding of the phosphorus atom to the nucleophilic $\mathrm{O} \gamma$ atom of the catalytic serine residue, the leaving group is released to afford a covalent protein-phosphonate adduct. Release of a second leaving group is prevented because of the pentavalency of the phosphorus atom. Therefore, cleavage of the phosphorylating agent

[*] In recognition of his outstanding contributions to the field of coordination chemistry.

[a] Chemical Biology \& Organic Synthesis, Debye Institute for Nanomaterials Science, Faculty of Science, Utrecht University, Padualaan 8, $3584 \mathrm{CH}$ Utrecht, The Netherlands

Fax: +31-30-2523615

E-mail: g.vankoten@uu.nl r.j.m.kleingebbink@uu.nl

[b] Membrane Enzymology, Faculty of Science, Utrecht University, Padualaan 8, $3584 \mathrm{CH}$ Utrecht, The Netherlands

[c] Crystal and Structural Chemistry, Faculty of Science, Utrecht University,

Padualaan 8, $3584 \mathrm{CH}$ Utrecht, The Netherlands

$\square$ Supporting information for this article is available on the WWW under http://www.eurjic.org or from the author. from an inhibited hydrolase is extremely slow at normal $\mathrm{pH}$ values $(<\mathrm{pH} \approx 11$ ), and for this reason the reaction is regarded as an irreversible process. ${ }^{[5]}$

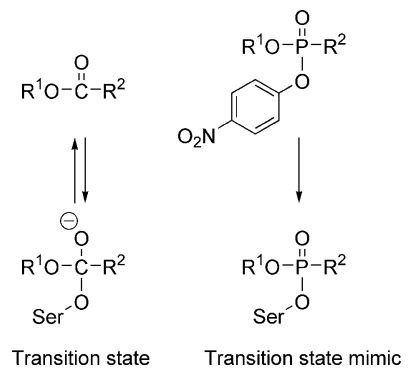

Figure 1. Left: transition state of ester hydrolysis by lipases; right: the covalently attached phosphonate as the transition state analogue.

Recently, we reported the attachment of active-site-directed complexes (ASDCs) to the lipase cutinase, in which we implemented $p$-nitrophenylphosphonate esters as covalent inhibitors (1, Figure 2). ${ }^{[6]}$ The phosphonate esters were linked by a propyl tether to terdentate pincer metal complexes comprising the well-known ECE-pincer type ligand $\left\{\mathrm{ECE}=\left[2,6-\left(\mathrm{CH}_{2} \mathrm{E}\right)_{2} \mathrm{C}_{6} \mathrm{H}_{3}\right]^{-} ; \mathrm{E}=\right.$ e.g. $\left.\mathrm{PR}_{2}, \mathrm{SR}, \mathrm{NR}_{2}\right\}{ }^{[7]}$ Pincer metal complexes have proven to be versatile compounds and have found many applications in the field of homogeneous catalysis, ${ }^{[8]}$ sensoring materials,,${ }^{[9]}$ and supra- 

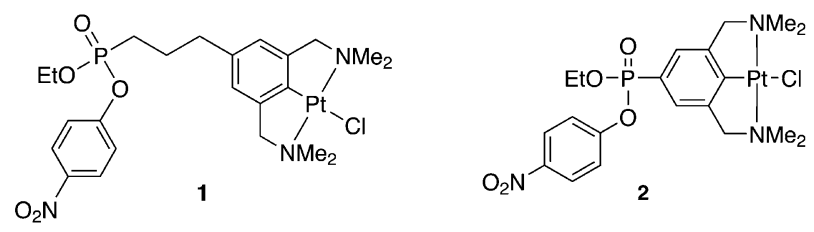

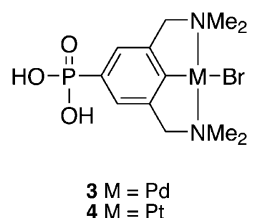

Figure 2. Phosphonate-appended NCN-pincer metal complexes.

molecular assemblies. ${ }^{[10]}$ From molecular modeling studies and preliminary X-ray crystal structures of some of these protein-pincer metal hybrids, ${ }^{[1]}$ we now know that the propyl linker places the metal center at the periphery of the protein. Additionally, since the active site is well exposed at the protein surface, the metal pincer head group is located at the interface between the protein and the solvent.

For potential applications of such ASDCs in the area of protein diagnostics, ${ }^{[12]}$ in non-natural (bio)catalysis, ${ }^{[13]}$ or as supramolecular building blocks using the unique properties of the pincer moiety, we have become interested in placing the metal atom more deeply in the active site of cutinase. For this reason, we have chosen a system in which a phosphonate moiety is directly attached to the aromatic ring of the metal complex (see 2, Figure 2). This will place the metal center well inside the active site of cutinase and potentially other serine hydrolases (the superfamily to which cutinase belongs).${ }^{[14]}$ Besides phosphonate esters, also phosphonic acid derivatives have been reported to be active inhibitors of serine hydrolases in various cases. However, they have never been tested for lipases, e.g. cutinase. ${ }^{[15]}$ From a synthetic point of view, pincer-containing phosphonic acids 3 and $\mathbf{4}$ (Figure 2) are of interest, since the route to their synthesis appeared to be considerably shorter than the synthetic route to phosphonate compounds like $\mathbf{1}$ and $\mathbf{2}^{[16]}$ Herein, we report the synthesis of ASDCs 2, 3, and 4, as well as their behavior in inhibition studies with cutinase.

\section{Results and Discussion}

\section{Synthesis of Complexes 2, 3, and 4}

Compound 2 was prepared in a five-step reaction sequence starting from 2-bromo-1,3-bis[(dimethylamino)methyl]-5-iodobenzene ${ }^{[17]}$ and ethyl chloro- $N, N$-dimethylamino-phosphinate (5, Scheme 1). The formation of the $\mathrm{P}-\mathrm{C}$ bond was achieved by selective iodo-lithio exchange using $t \mathrm{BuLi},{ }^{[18]}$ followed by reaction of the lithiated intermediate with 5 to obtain phosphinate-pincer adduct $\mathbf{6}$. Cycloplatination of 6 was effected with [Pt(tol-4) $\left.\left(\mathrm{SEt}_{2}\right)\right]_{2}{ }^{[19]}$ to give organoplatinum complex 7. Next, a halide exchange reaction using $\mathrm{AgBF}_{4}$ and $\mathrm{NaCl}$ was performed, to prevent halogen scrambling in the subsequent reaction step, ${ }^{[20]}$ which resulted in complex 8. The $p$-nitrophenyl group was introduced by first reacting 8 with dry $\mathrm{HCl}\left(1 \mathrm{M}_{\text {in }} \mathrm{Et}_{2} \mathrm{O}\right)$, thereby replacing the $\mathrm{NMe}_{2}$ group on the phosphorus atom by a chlorine atom. Subsequent substitution of the chloro atom by a $p$-nitrophenyl moiety by treating the intermediate with $p$-nitrophenol in the presence of $\mathrm{NEt}_{3}$ provided the desired product $\mathbf{2}$. The phosphonic acid pincer complexes $\mathbf{3}$ and 4 were prepared from previously reported complexes 9 and 10, respectively. ${ }^{[16]}$ Treatment of a solution of either complex 9 or $\mathbf{1 0}$ with ten equivalents of bromotrimethylsilane in dichloromethane, followed by addition of dry methanol, generated the phosphonic acids (Scheme 2). Full conversion of the starting materials was confirmed by ${ }^{31} \mathrm{P}\left\{{ }^{1} \mathrm{H}\right\}$ NMR $\left(\mathrm{D}_{2} \mathrm{O}\right)$ analysis, showing a singlet at $\delta=14.38$ and $19.01 \mathrm{ppm}$ for $\mathbf{3}$ and $\mathbf{4}$, respectively. Both complexes are water-soluble and nearly insoluble in dichloromethane and benzene.
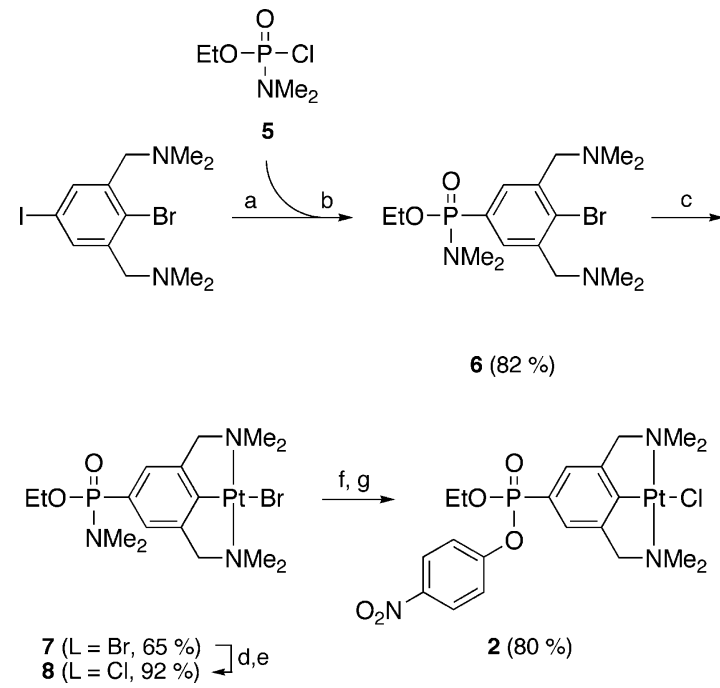

Scheme 1. Synthesis of 2. Reagents and conditions: (a) $t \mathrm{BuLi}$ ( 2 equiv.), $\mathrm{Et}_{2} \mathrm{O},-100{ }^{\circ} \mathrm{C}$. (b) $-100{ }^{\circ} \mathrm{C} \rightarrow$ room temp., $2 \mathrm{~h}$. (c) $\left[\mathrm{Pt}\left(\text { tol-4) }\left(\mathrm{SEt}_{2}\right)\right]_{2}, \mathrm{C}_{6} \mathrm{H}_{6}\right.$, reflux, $1 \mathrm{~h}$. (d) $\mathrm{AgBF}_{4}$, acetone, $\mathrm{H}_{2} \mathrm{O}$, room temp., 1 h. (e) excess $\mathrm{NaCl}, \mathrm{CH}_{2} \mathrm{Cl}_{2}$, room temp., 2 h. (f) $1 \mathrm{M}$ $\mathrm{HCl} / \mathrm{Et}_{2} \mathrm{O}$ (5 equiv.), $\mathrm{C}_{6} \mathrm{H}_{6}$, room temp., $3 \mathrm{~h}$. (g) p-nitrophenol, $\mathrm{NEt}_{3}, \mathrm{C}_{6} \mathrm{H}_{6}$, room temp., $1 \mathrm{~h}$.
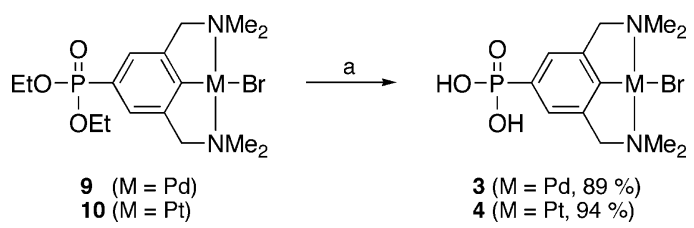

Scheme 2. Synthesis of phosphonic acid pincer complexes. Reagents and conditions: (a) 10 equiv. TMSBr, $\mathrm{CH}_{2} \mathrm{Cl}_{2}, 4 \mathrm{~h}$, room temp., followed by dry $\mathrm{MeOH}$.

Attempts to obtain single crystals suitable for X-ray diffraction analysis for $\mathbf{2}, \mathbf{3}$, and $\mathbf{4}$ failed. We succeeded, however, in obtaining suitable crystals for $\mathbf{9}$ and $\mathbf{1 0}$ by slow evaporation of a concentrated solution in dichloromethane. 
Both complexes are isomorphous in the solid state (see Supporting Information for crystallographic details). As a representative picture, the molecular structure of 9 in the solid state is shown in Figure 3.

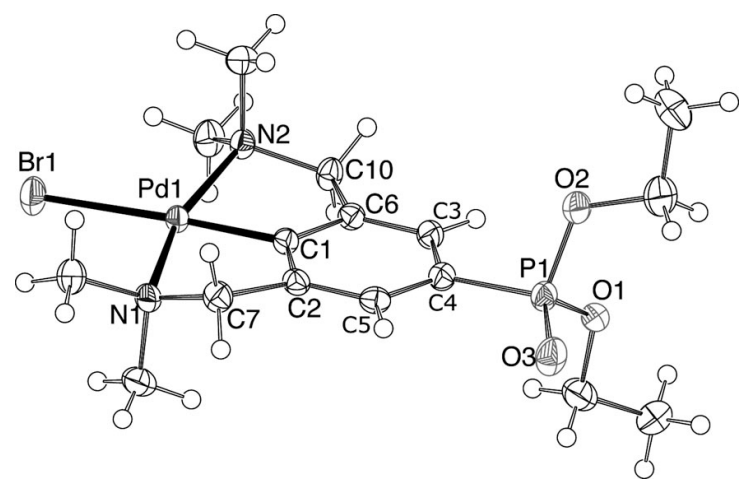

Figure 3. View of the molecular structure of 9 in the crystal. Displacement ellipsoids are drawn at the $50 \%$ probability level. The analogous Pt complex $\mathbf{1 0}$ is isomorphous in the solid state.

\section{Inhibitory Activity of NCN-Pincer Phosphonate Ester 2}

In order to quantitatively determine the inhibition rate of cutinase with ASDCs $\mathbf{1}$ and $\mathbf{2}$, we typically monitored the concomitant release of $p$-nitrophenolate during the inhibition process with UV/Vis spectroscopy at $400 \mathrm{~nm}$ (Scheme 3). Treatment of a buffered cutinase solution ( $25 \mu \mathrm{M}$ cutinase, buffer solution containing $0.1 \%$ Triton X$100,50 \mathrm{~mm}$ Tris- $\mathrm{HCl})$ at $\mathrm{pH} 8.0($ Scheme 3$)$ with an excess of ASDC 1 or 2 (10 equiv.) gave 100\% inhibition of cutinase in both cases (data not shown). However, this experiment also revealed that the inhibition of cutinase with 2 was $>500$ times slower as compared to inhibition with $\mathbf{1}$.

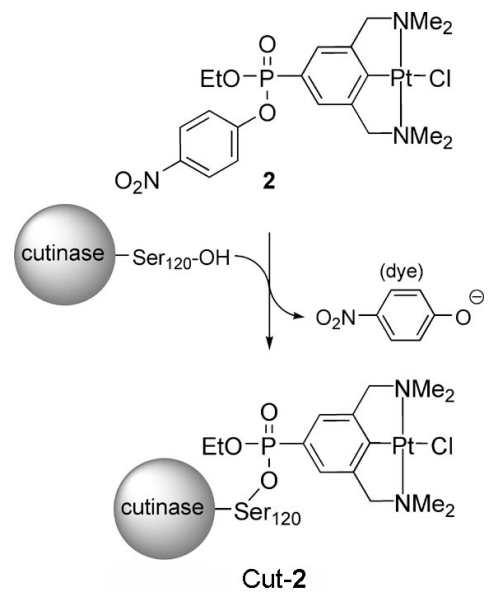

Scheme 3. ASDC reaction of 2 with cutinase.

This is attributed to the $\mathrm{C} 3$-tether that is present in $\mathbf{1}$ and not in $\mathbf{2}$, which gives rise to less steric hindrance during the inhibition process in the case of $\mathbf{1}$. The consequence of this much slower inhibition rate in the case of $\mathbf{2}$ is that also the slow spontaneous hydrolysis of $\mathbf{2}$ (Scheme 4), a process releasing $p$-nitrophenolate, potentially becomes competitive and cannot be ignored anymore when monitoring $p$-nitrophenolate release as a measure of cutinase inhibition yields. The $\mathrm{P}-\mathrm{O}$ bond between the phosphonate moiety and the $p$ nitrophenol group is rather labile and can lead to "spontaneous" hydrolysis under the applied reaction conditions ( $\mathrm{pH}$ 8.0). Therefore, for our inhibition process, we decided to monitor the course of the reaction spectrophotometrically by using a double beam UV/Vis spectrometer in which a control mixture without cutinase was placed in the reference cuvette.<smiles>[CH]C1CN(C)Cc2c1cc(P(=O)(OCC)Oc1ccc([N+](=O)[O-])cc1)cc2C(Cl)(Cl)Cl</smiles><smiles>CCOP(=O)(OCC)c1cc2c([P+](C)(Cl)CN(C)C)c(c1)CN(C)C2</smiles>

Scheme 4. Base-catalyzed hydrolysis of $\mathbf{2}$ forming $p$-nitrophenolate $\left[\mathrm{pH} 8.0, p K_{\mathrm{a}}(p\right.$-nitrophenol $\left.)=7.15\right]$.

In order to get a more detailed picture of the inhibition process with $\mathbf{2}$, only two equivalents of ASDC $\mathbf{2}$ in acetonitrile $(5 \mathrm{~mm})$ were added to a buffered cutinase solution. Monitoring the absorbance at $400 \mathrm{~nm}$ gave the reaction profile as presented by curve A in Figure 4. ASDC 2 is used as a racemate and, because cutinase is known to react with enantiomeric preference (the phosphorus atom in $\mathbf{2}$ is a stereogenic center), ${ }^{[21]}$ addition of two equivalents of $\mathbf{2}$ was necessary to ensure the presence of a stoichiometric amount of the preferred, fast-reacting enantiomer with respect to

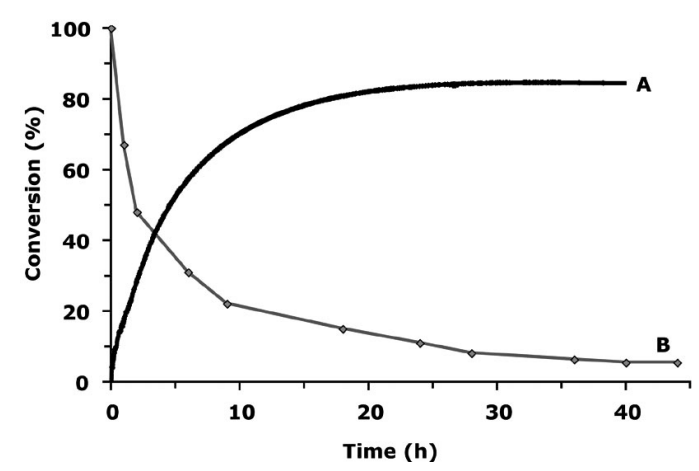

Figure 4. Conversion of cutinase upon reaction with 2. Curve A: release of $p$-nitrophenolate monitored by the increase in absorbance at $400 \mathrm{~nm}$ relative to blank. Decay curve B: decrease of enzymatic activity monitored by using a spectrometric enzyme activity assay containing $p$-nitrophenyl butyrate ester $(0.25 \mathrm{~mm}, \mathrm{pH}$ 8.0). Reagents and conditions: $25 \mu \mathrm{M}$ cutinase, $50 \mu \mathrm{M}$ ASDC 2, buffer: $50 \mathrm{~mm}$ Tris- $\mathrm{HCl}, 0.1 \%$ Triton $\mathrm{X}-100$ at $\mathrm{pH}$ 8.0. 
cutinase. Curve A in Figure 4 suggests that an incomplete reaction occurs and only $85 \%$ of the lipase is converted into the hybrid Cut-2 after 40 hours. To confirm this result, we performed an experiment in which the cutinase inhibition reaction was followed by assaying the residual carboxylic ester hydrolysis activity of cutinase with $p$-nitrophenyl butyrate ester as a substrate ${ }^{[6]}$ At regular intervals, aliquots of the inhibition reaction mixture were added to a buffer solution containing $p$-nitrophenyl butyrate ester. The rate of release of $p$-nitrophenol was monitored as a direct measure for the concentration of residual free enzyme (Figure 4, curve B). According to this experiment, a $94 \%$ cutinase inhibition (and not $85 \%$, see curve A) was observed after $40 \mathrm{~h}$. Between 40 and $48 \mathrm{~h}$, no change in cutinase inhibition was observed anymore, indicating that the reactive intermediate of $\mathbf{2}$ was completely converted.

Since curve A and B in Figure 4 give different inhibition yields of cutinase, these results indicate indeed that, in parallel with the slow formation of the Cut-2 hybrid during the inhibition experiment, a kinetically relevant side reaction occurs in which also $p$-nitrophenol is released. Therefore, we decided to monitor the reference cuvette with UV/Vis spectroscopy (i.e. $50 \mu \mathrm{M}$ of 2 in $0.1 \%$ Triton X-100, $50 \mathrm{~mm}$ Tris- $\mathrm{HCl}, \mathrm{pH} 8.0$ ), in order to determine whether this was a result of spontaneous hydrolysis of $\mathbf{2}$ (Scheme 4) under the applied reaction conditions ( $\mathrm{pH} 8.0)$. At 20 min time intervals UV/Vis spectra of this solution were measured for a total period of $48 \mathrm{~h}$. The combined spectra, presented in Figure 5, show a decrease in absorbance between 272 $292 \mathrm{~nm}$ and an increase at $400 \mathrm{~nm}$, the latter clearly showing that in this time regime a substantial amount of $p$-nitrophenolate is released (note the presence of a single isosbestic point at $332 \mathrm{~nm})$. After $40 \mathrm{~h}, 15 \%(7.5 \mu \mathrm{M})$ of 2 is hydrolyzed in the reference cuvette (see inset of Figure 5). This means that in our inhibition cuvette two competitive reactions take place, both of which release $p$-nitrophenolate: (1) cutinase inhibition with 2 (Scheme 3) and (2) spontaneous hydrolysis of 2 under the reaction conditions (Scheme 4). Control experiments showed that, during this time frame $(40 \mathrm{~h})$, the catalytic lipase activity in the hydrolysis reaction of $p$-nitrophenyl butyrate ester by cutinase is not affected, ruling out the possibility that the observed discrepancy between curves A and B is caused by lipase deactivation or degradation. Therefore, from curve B (Figure 4) it can be concluded that $6 \%$ hydrolysis of the reactive enantiomer of $2^{[22]}$ has occurred during the inhibition process as only $94 \%$ cutinase inhibition was found. It should be noted that the cutinase inhibition does not change anymore after $40 \mathrm{~h}$, meaning that the inhibition rate of the unreactive enantiomer of $\mathbf{2}$ with cutinase is too low to be measured and can therefore be ignored here $(85 \%$ of this enantiomer is still present after $40 \mathrm{~h}$ ). Since in the reference cuvette $15 \%$ hydrolysis of the reactive enantiomer occurred, inhibition curve A was overcompensated by $9 \%$ (the difference in spontaneous hydrolysis of $\mathbf{2}$ in the inhibition cuvette and the reference cuvette) at the 40 -h time point. This is exactly the observed difference in cutinase inhibition as determined by the two analysis techniques ( $85 \%$ vs. $94 \%$, curves A and
B, respectively, Figure 4). Therefore, the different degrees of spontaneous hydrolysis of the preferred enantiomer of $\mathbf{2}$ in the inhibition cuvette vs. the reference cuvette fully account for the observed differences in cutinase inhibition rates as determined by two independent experiments. ${ }^{[23]}$

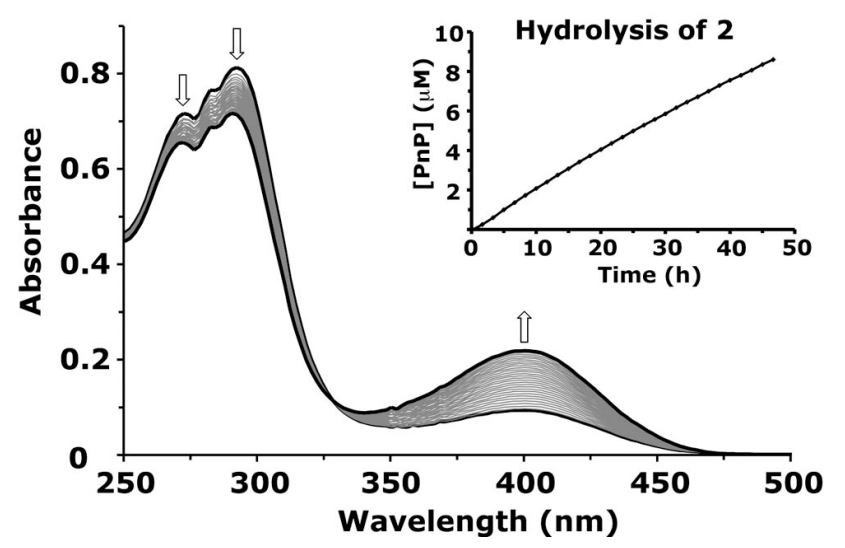

Figure 5. UV/Vis spectra of $2(50 \mu \mathrm{M})$ in a buffer solution at $\mathrm{pH}$ $8.0(0.1 \%$ Triton $\mathrm{X}-100,50 \mathrm{~mm}$ Tris- $\mathrm{HCl})$ recorded over $48 \mathrm{~h}$ at $20 \mathrm{~min}$ intervals. The inset shows the hydrolysis of $2(50 \mu \mathrm{M}) \mathrm{re}-$ corded at $400 \mathrm{~nm}$ under the same conditions $\left(k_{\mathrm{h}}=1.13 \times 10^{-6} \mathrm{~s}^{-1} /\right.$ $\left.6.8 \times 10^{-5} \mathrm{~min}^{-1}\right) .^{[22]}$

\section{Analysis of the Cut-2 Hybrid by ESI-MS}

In order to synthesize a pure Cut-2 hybrid sample for ESI-MS analysis, an additional experiment was conducted in which cutinase $(25 \mu \mathrm{M})$ was allowed to react with a 10 fold excess of $2(250 \mu \mathrm{M})$. Within $5 \mathrm{~h}$, full conversion to the Cut-2 hybrid was obtained. This was confirmed by a control experiment using the $p$-nitrophenyl butyrate ester lipase activity assay. No residual ester hydrolysis activity of cutinase was found, proving that cutinase was indeed com-

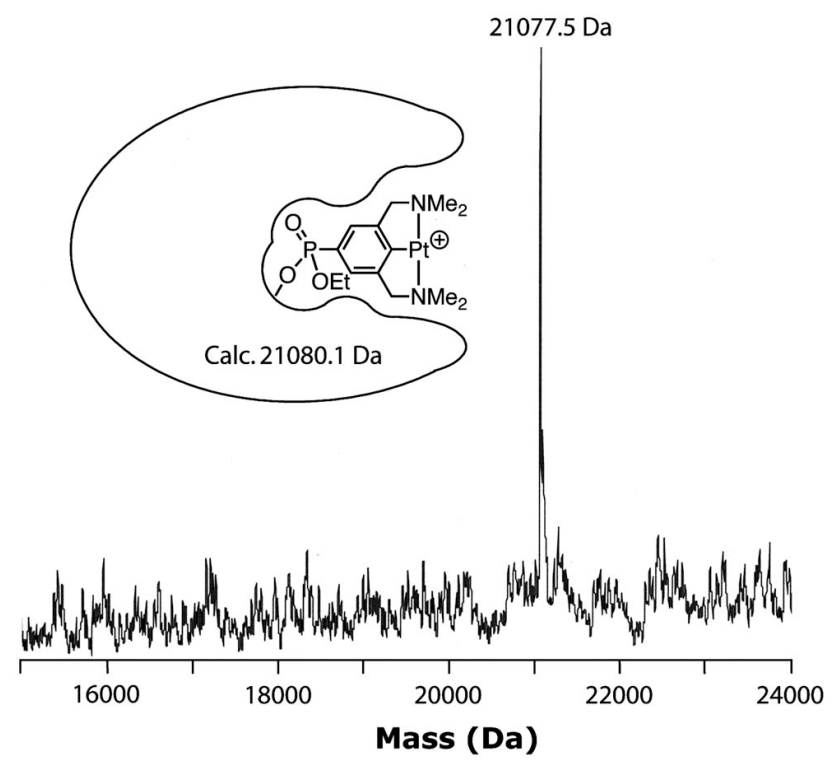

Figure 6. ESI-mass spectrum of the cutinase-NCN-pincer-PtCl complex hybrid Cut-2. 
pletely inhibited and that all the active sites were modified by the organometallic pincer complex. After dialysis of the mixture, a pure Cut-2 sample was obtained, which illustrates the simplicity of this modification strategy. The ESImass spectrum showed the signal of Cut-2 minus the chlorine atom $\left(M_{\mathrm{w}}: 21077.5 \mathrm{Da}\right.$, Figure 6), a common observation in the case of pincer complexes. Importantly, no peak at the $\mathrm{m} / \mathrm{z}$ of free cutinase was found $\left(M_{\mathrm{w}}: 20619\right)$. This provides an unambiguous proof for the quantitative formation of the cutinase-NCN-pincer-PtCl complex hybrid Cut-2, and illustrates the stability of the SerO-P bond towards hydrolysis. ${ }^{[5]}$

\section{Inhibitory Activity of ASDCs 3 and 4}

To determine whether phosphonic acids $\mathbf{3}$ and $\mathbf{4}$ are able to interact with the active site of cutinase, we performed a similar incubation experiment as described for 2. Cutinase ( $25 \mu \mathrm{M}$, in $50 \mathrm{~mm}$ Tris- $\mathrm{HCl}, 0.1 \%$ Triton $\mathrm{X}-100$ at $\mathrm{pH} 8.0$ ) was exposed to either 1 or 100 equiv. of $\mathbf{3}$ or $\mathbf{4}$. After incubating the solution for $48 \mathrm{~h}$, the residual hydrolytic activity of cutinase was tested with the standard activity assay comprising $p$-nitrophenyl butyrate ester in a Tris- $\mathrm{HCl}$ buffer at $\mathrm{pH}$ 8.0. Any decrease in hydrolytic activity would imply blocking of the active site of cutinase. However, with $\mathbf{3}$ and 4 no decrease in hydrolysis activity of cutinase towards the $p$-nitrophenol butyrate ester was observed, not even when 100 equiv. of either $\mathbf{3}$ or $\mathbf{4}$ were used. Thus, although others have reported similar arylphosphonic acid structures to be active towards serine hydrolases, no formation of a Cut3 or Cut-4 hybrid seems to occur. Becker and co-workers reported that hydrophobic interactions of side chains of the inhibitor with a lipase have a minor influence on the inhibitory power of phosphonates. ${ }^{[24]}$ In the case of cutinase, the active site is accessible for water-soluble as well as waterinsoluble esters. This is due to the absence of a so-called lid, covering the active site, and for this reason cutinase does not show any interfacial activation towards hydrophobic surfaces such as lipid micelles as common lipases do. A possible explanation for the lack of inhibitory activity by $\mathbf{3}$ and $\mathbf{4}$ could be that these complexes exist in the basic buffer solution as ionic complexes, which probably interact with the hydrophobic surface of cutinase in a repelling manner, thereby preventing them from entering the active site. Related to this, Freedman et al. reported the inhibitory activity of related phenylphosphonic and phenylphosphinic acids toward acetylcholine esterase, for which strong inhibition activities were found in some examples. ${ }^{[15]}$ The enzyme has an active site similar to that of cutinase (i.e. an serine hydrolase with a Glu, His, Ser catalytic triad), however, the catalytic cavity is more exposed and larger. In the case of acetylcholine esterase, phosphonic acid inhibitors are able to interact with the active site because there is less interaction with the protein surface around the active site. Because of its narrow catalytic pocket, this is apparently not the case for cutinase, which provides an alternative explanation for the lack of inhibition power of $\mathbf{3}$ and $\mathbf{4}$.

\section{Conclusions}

A new ASDC (2), having a phosphonate $p$-nitrophenyl ester directly attached to an aromatic organometallic pincer moiety, is reported. This probe shows good inhibitory activity towards cutinase, affording an organometallic-cutinase hybrid in which the organometallic head group is now positioned in the chiral surroundings of the active site of cutinase. This in contrast with the previously reported ASDC 1, which has the metal center positioned at the periphery of the of Cut-1 lipase hybrid as determined by Xray crystallographic studies. ${ }^{[1]}$ The inhibition rate of $\mathbf{2}$ with cutinase was found to be $>500$ times slower than that of $\mathbf{1}$, which is attributed to increased steric hindrance in $\mathbf{2}$. Consequently, in the case of very slow inhibition rates (as with 2), one cannot simply rely on monitoring the increase in color intensity in solution as a measure of protein inhibition, since slow side reactions (hydrolysis of 2) now become significant. In such cases, appropriate control experiments (enzyme activity tests) are needed to confirm the inhibition yield. The isolation of pure Cut-2 hybrid was confirmed by ESI-MS spectrometry, showing the absence of wild-type cutinase in the sample: only the signal corresponding to Cut-2 was observed. NCN-pincer metal phosphonic acids on the other hand were found to be inactive as inhibitors towards cutinase. This latter result was attributed to unfavorable polar-apolar repulsion interactions, showing the importance of the $p$-nitrophenol leaving group in the use of ASDCs for lipase modification.

Due to the specificity of $p$-nitrophenyl phosphonate esters for serine hydrolases, ${ }^{[14]}$ this methodology should provide relatively easy access to a whole range of organometallic-enzyme hybrids. Therefore, the presented protocol provides a straightforward and unique approach for further fine-tuning of the organometallic-enzyme hybrid for diagnostic (transition-metal bioprobes) and catalytic (artificial metalloenzymes) applications.

\section{Experimental Section}

General Remarks: All organic and organometallic reactions were conducted under a dry dinitrogen atmosphere by using standard Schlenk techniques. Organic solvents were dried with appropriate materials and distilled prior to use. All reagents were obtained commercially and used without further purification unless stated otherwise. Triton X-100 was purchased from Serva and tris(hydroxymethyl)aminomethane from J. T. Baker. Buffer solutions were prepared with Milli-Q grade water. Purification of water (18.2 Mécm) was performed with the Milli-Q Synthesis system (Millipore; Quantum Ultrapure). ${ }^{1} \mathrm{H}$ and ${ }^{13} \mathrm{C}\left\{{ }^{1} \mathrm{H}\right\}$ NMR spectra were recorded at $298 \mathrm{~K}$ with a Varian Inova 300 spectrometer at 300 and $75 \mathrm{MHz}$, respectively, and ${ }^{31} \mathrm{P}\left\{{ }^{1} \mathrm{H}\right\}$ NMR spectra were recorded at $298 \mathrm{~K}$ with a Bruker AC200 instrument at $81 \mathrm{MHz}$. All NMR chemical shifts are in ppm and are referenced to residual solvents $\left({ }^{31} \mathrm{P}\left\{{ }^{1} \mathrm{H}\right\}\right.$ NMR shifts to $\mathrm{H}_{3} \mathrm{PO}_{4}$ ). The MALDI-TOF mass spectra were acquired by using a Voyager-DE Biospectrometry Workstation (PerSeptive Biosystems Inc., Framingham, Ma, USA) mass spectrometer. Sample solutions with an approximate concentration of 20 $30 \mathrm{mg} / \mathrm{mL}$ in $\mathrm{CH}_{2} \mathrm{Cl}_{2}$ or thf were prepared. The matrix was 5-chlo- 
rosalicylic acid (csa) with an approximate concentration of 20 $30 \mathrm{mg} / \mathrm{mL}$. The sample $(0.2 \mu \mathrm{L})$ and the matrix solution $(0.2 \mu \mathrm{L})$ were combined and placed on a golden MALDI target plate and analyzed after evaporation of the solvents. $\left[\mathrm{Pt}(\mathrm{tol}-4)_{2}\left(\mathrm{SEt}_{2}\right)\right]_{2},{ }^{[19]} 2-$ bromo-1,3-bis[(dimethylamino)methyl]-5-iodobenzene, ${ }^{[17]} \mathbf{9},{ }^{[16]}$ and $\mathbf{1 0}^{[16]}$ were prepared according to described procedures. Microanalyses were performed by Kolbe, Mikroanalytisches Laboratorium (Mülheim a/d Ruhr, Germany). UV/Vis spectroscopic experiments were performed at room temperature by using a Carey-100 spectrometer. Electrospray ionization (ESI) mass spectra of the wild-type cutinase and modified cutinase were recorded with a Finnigan LC-Q ion trap mass spectrometer. All samples were introduced by using a nanoflow electrospray source (Protana, Odense, Denmark).

Inhibitory Activity of 2: To a buffer solution ( $0.1 \%$ Triton X-100, $50 \mathrm{~mm}$ Tris- $\mathrm{HCl}, \mathrm{pH} 8.0)$ containing wild-type cutinase $(25 \mu \mathrm{M}$, $25 \mathrm{nmol}, 0.52 \mathrm{mg})$ was added a solution of 2 in $\mathrm{CH}_{3} \mathrm{CN}(10 \mu \mathrm{L}$, $5 \mathrm{~mm}, 50 \mu \mathrm{mol})$. The reaction was followed by UV/Vis spectroscopy until it was complete, which was confirmed by a plateau that appeared in the UV absorption curve at $400 \mathrm{~nm}$. The conversion rate of the reaction was calculated from the increase in absorbance generated by the $p$-nitrophenolate anion by using an experimentally determined molar extinction coefficient of $14580 \mathrm{M}^{-1} \mathrm{~cm}^{-1}$ in this buffer.

Inhibitory Activity Studies with 3 and 4: To a buffer solution $(0.1 \%$ Triton $\mathrm{X}-100,50 \mathrm{~mm}$ Tris-HCl, $\mathrm{pH} 8.0$ ) containing wild-type cutinase $(25 \mu \mathrm{M}, 25 \mathrm{nmol}, 0.52 \mathrm{mg})$ was added a solution of 7 or 8 in water $(50 \mu \mathrm{L}, 50 \mathrm{~mm}, 2.5 \mathrm{mmol})$. The samples were incubated for $48 \mathrm{~h}$ at room temperature. Afterwards, the free enzyme concentration was determined by examining the residual catalytic activity using the UV/Vis spectroscopic assay containing the substrate $p$ nitrophenol butyrate ester as described below. In a control experiment, cutinase without a phosphonic acid complex in the buffer solution was also tested for ester hydrolysis activity.

Ester Hydrolysis Activity of Cutinase: The catalytic activity of cutinase was determined by UV/Vis spectroscopy on $p$-nitrophenol butyrate ester $(0.25 \mathrm{~mm})$ in the presence of Triton X-100 (100 mM) and Tris- $\mathrm{HCl}(10 \mathrm{~mm})$ at $\mathrm{pH} 8.0$. Aliquots $(5 \mu \mathrm{L})$ were taken and added to the assay. Activities were calculated from the increase in absorbance at $400 \mathrm{~nm}$.

Hydrolysis of 2: The hydrolysis reaction of the phosphonate ester in ASDC 2, caused by reaction of $\mathbf{2}$ with the basic buffer solution $(0.1 \%$ Triton $\mathrm{X}-100,50 \mathrm{~mm}$ Tris- $\mathrm{HCl}, \mathrm{pH} 8.0)$ and thereby releasing $p$-nitrophenol, was examined over $48 \mathrm{~h}$ by recording UV/Vis spectra at $400 \mathrm{~nm}$ at $20 \mathrm{~min}$ time intervals.

Preparation of Samples for Mass Spectrometry Analysis: Cutinase $(25 \mu \mathrm{M})$ in a Tris-HCl buffer solution $(10 \mathrm{~mm}, \mathrm{pH} 8.0)$ was incubated for $48 \mathrm{~h}$ with excess of 2 (10 equiv.). Completion of the reaction was confirmed by determining the residual catalytic hydrolysis activity of cutinase. The clear yellow solutions were subsequently dialyzed for $2 \times 12 \mathrm{~h}$ with the same buffer. Prior to measurements of ESI mass spectra, the solutions were diluted to $2-5 \mu \mathrm{M}$ with $\mathrm{CH}_{3} \mathrm{CN}$.

Ethyl Chloro- $N, N$-dimethylaminophosphinate (5): Dimethylamine $(8.29 \mathrm{~g}, 12.75 \mathrm{~mL}, 182.12 \mathrm{mmol})$ in $\mathrm{Et}_{2} \mathrm{O}(20 \mathrm{~mL})$ was added dropwise to a solution of dichloroethylphosphonate in $\mathrm{Et}_{2} \mathrm{O}(30 \mathrm{~mL})$ at $0{ }^{\circ} \mathrm{C}$. The mixture was stirred for $2 \mathrm{~h}$ at room temperature, the precipitated salt was filtered off, and the residue was washed with $\mathrm{Et}_{2} \mathrm{O}(2 \times 20 \mathrm{~mL})$. The combined filtrate and washings were concentrated to dryness to afford an orange oil. The crude product was distilled under reduced pressure $\left(54^{\circ} \mathrm{C} / 12\right.$ Torr $)$ to obtain the product as colorless oil. Yield: $11.84 \mathrm{~g}(75 \%) .{ }^{1} \mathrm{H}$ NMR $\left(\mathrm{CDCl}_{3}\right)$ : $\delta=4.19\left(\mathrm{~m}, \mathrm{CH}_{2} \mathrm{O}, 2 \mathrm{H}\right), 2.67\left[\mathrm{~d},{ }^{3} J_{\mathrm{H}, \mathrm{P}}=13.92 \mathrm{~Hz}, 6 \mathrm{H}, \mathrm{N}-\right.$ $\left.\left(\mathrm{CH}_{3}\right)_{2}\right], 1.35\left[\mathrm{t},{ }^{3} J_{\mathrm{C}, \mathrm{P}}=5.99 \mathrm{~Hz}, 3 \mathrm{H}, \mathrm{CH}_{3} \mathrm{CH}_{2} \mathrm{O}\right] \mathrm{ppm} .{ }^{31} \mathrm{P} \mathrm{NMR}$ $\left(\mathrm{CDCl}_{3}\right): \delta=18.84$ (s) ppm. ${ }^{13} \mathrm{C} \mathrm{NMR}\left(\mathrm{CDCl}_{3}\right): \delta=64.5\left(\mathrm{~d},{ }^{2} J_{\mathrm{C}, \mathrm{P}}\right.$ $\left.=6.0 \mathrm{~Hz}, \mathrm{CH}_{2} \mathrm{O}\right), 36.9\left[\mathrm{~d},{ }^{2} J_{\mathrm{C}, \mathrm{P}}=2.8 \mathrm{~Hz}, \mathrm{PN}\left(\mathrm{CH}_{3}\right)_{2}\right], 16.1\left(\mathrm{~d},{ }^{2} J_{\mathrm{C}, \mathrm{P}}\right.$ $=7.8 \mathrm{~Hz}, \mathrm{CH}_{3} \mathrm{CH}_{2} \mathrm{O}$ ) ppm. $\mathrm{C}_{4} \mathrm{H}_{11} \mathrm{ClNO}_{2} \mathrm{P}$ (171.56): calcd. $\mathrm{C} 28.00$, $\mathrm{H}$ 6.46, N 8.16; found C 27.88, H 6.56, N 8.28. GC-MS: calcd. 171.56; found 171 .

Ethyl $\quad P$-\{4-bromo-1,3-bis [(dimethylamino)methyl]phenyl\}- $N, N$-dimethylaminophosphinate (6): A solution of 2-bromo-1,3-bis[(dimethylamino)methyl]-5-iodobenzene $(1.48,3.73 \mathrm{mmol})$ in $\mathrm{Et}_{2} \mathrm{O}$ $\left(30 \mathrm{~mL}\right.$ ) was cooled to $-100^{\circ} \mathrm{C}$ and $t \mathrm{BuLi}$ (2 equiv., $4.97 \mathrm{~mL}$, $7.45 \mathrm{mmol}, 1.5 \mathrm{M}$ in pentane) was added dropwise. Stirring was continued for $10 \mathrm{~min}$ at this temperature and the reaction mixture was subsequently quenched with $\mathbf{5}(0.63 \mathrm{~g}, 3.73 \mathrm{mmol})$ in $\mathrm{Et}_{2} \mathrm{O}(10 \mathrm{~mL})$. The reaction mixture was stirred for $2 \mathrm{~h}$ at room temperature and then water $(40 \mathrm{~mL})$ was added. The aqueous phase was separated and the organic phase was washed with $\mathrm{NaOH}(2 \times 30 \mathrm{~mL})$ and brine. Afterwards it was dried with $\mathrm{MgSO}_{4}$. The mixture was filtered and the filtrate was concentrated in vacuo to afford the product as yellowish oil. Yield: $1.24 \mathrm{~g}(82 \%) .{ }^{1} \mathrm{H}$ NMR $\left(\mathrm{CDCl}_{3}\right): \delta=$ $7.64\left(\mathrm{~d},{ }^{3} J_{\mathrm{H}, \mathrm{P}}=12.45 \mathrm{~Hz}, 2 \mathrm{H}, \mathrm{ArH}\right), 4.10\left(\mathrm{~m}, \mathrm{CH}_{2} \mathrm{O}, 2 \mathrm{H}\right), 3.54$ (s, $\left.\mathrm{ArCH}_{2} \mathrm{~N}, 4 \mathrm{H}\right), 2.66\left[\mathrm{~d},{ }^{3} J_{\mathrm{H}, \mathrm{P}}=9.89 \mathrm{~Hz}, 6 \mathrm{H}, \mathrm{PN}\left(\mathrm{CH}_{3}\right)_{2}\right], 2.28$ $\left[\mathrm{s}, \mathrm{N}\left(\mathrm{CH}_{3}\right)_{2}, 12 \mathrm{H}\right], 1.37\left(\mathrm{t},{ }^{3} \mathrm{~J}_{\mathrm{H}, \mathrm{H}}=6.96 \mathrm{~Hz}, 3 \mathrm{H}, \mathrm{CH}_{3} \mathrm{CH}_{2} \mathrm{O}\right) \mathrm{ppm}$. ${ }^{31} \mathrm{P}$ NMR $\left(\mathrm{CDCl}_{3}\right): \delta=24.33$ (s) ppm. ${ }^{13} \mathrm{C} \mathrm{NMR}\left(\mathrm{CDCl}_{3}\right): \delta=$ $139.5\left(\mathrm{~d},{ }^{3} J_{\mathrm{C}, \mathrm{P}}=14.0 \mathrm{~Hz}, \mathrm{ArC}\right), 132.2\left(\mathrm{~d},{ }^{2} J_{\mathrm{C}, \mathrm{P}}=11.0 \mathrm{~Hz}, \mathrm{ArC}\right)$, $131.40\left(\mathrm{~d},{ }^{4} J_{\mathrm{C}, \mathrm{P}}=4.0 \mathrm{~Hz}, \operatorname{ArC}\right), 129.0\left(\mathrm{~d},{ }^{1} J_{\mathrm{C}, \mathrm{P}}=173.8 \mathrm{~Hz}, \operatorname{ArC}\right)$, $64.1\left(\mathrm{~s}, \mathrm{ArCH}_{2} \mathrm{~N}\right), 60.7\left(\mathrm{~d},{ }^{2} J_{\mathrm{C}, \mathrm{P}}=5.4 \mathrm{~Hz}, \mathrm{CH}_{2} \mathrm{O}\right), 45.8[\mathrm{~s}, \mathrm{~N}-$ $\left.\left(\mathrm{CH}_{3}\right)_{2}\right], 36.6\left[\mathrm{~d},{ }^{2} J_{\mathrm{C}, \mathrm{P}}=4.2 \mathrm{~Hz}, \mathrm{PN}\left(\mathrm{CH}_{3}\right)_{2}\right], 16.6\left(\mathrm{~d},{ }^{3} J_{\mathrm{C}, \mathrm{P}}=6.1 \mathrm{~Hz}\right.$, $\mathrm{CH}_{3} \mathrm{CH}_{2} \mathrm{O}$ ) ppm. $\mathrm{C}_{16} \mathrm{H}_{29} \mathrm{BrN}_{3} \mathrm{O}_{2} \mathrm{P}$ (406.30): calcd. C 47.30, H 7.19, $\mathrm{N} 10.34$; found $\mathrm{C} 47.21, \mathrm{H} 7.25, \mathrm{~N} 10.12$.

Ethyl $P$-\{4-Bromoplatinum-1,3-bis[(dimethylamino)methyl]phenyl\}$\boldsymbol{N}, \boldsymbol{N}$-dimethylaminophosphinate (7): To a solution of $\mathbf{6}(0.36 \mathrm{~g}$, $0.88 \mathrm{mmol})$ in benzene $(10 \mathrm{~mL})$ was added solid $\left[\mathrm{Pt}(\mathrm{tol}-4)\left(\mathrm{SEt}_{2}\right)\right]_{2}$ $(0.37 \mathrm{~g}, 0.40 \mathrm{mmol})$ and the resulting mixture was subsequently heated to reflux for $1 \mathrm{~h}$. All volatiles were removed in vacuo and the remaining dark brown oil was dissolved in $\mathrm{CH}_{2} \mathrm{Cl}_{2}(10 \mathrm{~mL})$ and filtered through a short path of Celite. The filtrate was concentrated and washed with pentane $(3 \times 10 \mathrm{~mL}$, stirring for $30 \mathrm{~min})$ and $\mathrm{Et}_{2} \mathrm{O}$ $(2 \times 10 \mathrm{~mL}$, stirring for $30 \mathrm{~min})$. The resulting solid was dried in vacuo to obtain the product as an off-white solid. Yield: $0.38 \mathrm{~g}$ $(65 \%) .{ }^{1} \mathrm{H} \mathrm{NMR}\left(\mathrm{CDCl}_{3}\right): \delta=7.06\left(\mathrm{~d},{ }^{3} J_{\mathrm{H}, \mathrm{P}}=12.82 \mathrm{~Hz}, 2 \mathrm{H}\right.$, $\mathrm{ArH}), 3.96\left(\mathrm{~s},{ }^{3} \mathrm{~J}_{\mathrm{H}, \mathrm{Pt}}=46.88 \mathrm{~Hz}, 4 \mathrm{H}, \mathrm{CH}_{2} \mathrm{~N}\right), 3.92\left(\mathrm{~m}, 2 \mathrm{H}, \mathrm{CH}_{2} \mathrm{O}\right)$, $3.03\left[\mathrm{~s},{ }^{3} J_{\mathrm{H}, \mathrm{Pt}}=38.09 \mathrm{~Hz}, 12 \mathrm{H}, \mathrm{N}\left(\mathrm{CH}_{3}\right)_{2}\right], 2.61\left[\mathrm{~d},{ }^{3} J_{\mathrm{H}, \mathrm{P}}=8.06 \mathrm{~Hz}\right.$, $\left.6 \mathrm{H}, \mathrm{PN}\left(\mathrm{CH}_{3}\right)_{2}\right], 1.21\left(\mathrm{t},{ }^{3} J_{\mathrm{H}, \mathrm{H}}=6.96 \mathrm{~Hz}, 3 \mathrm{H}, \mathrm{CH}_{3} \mathrm{CH}_{2} \mathrm{O}\right) \mathrm{ppm}$. ${ }^{31} \mathrm{P}$ NMR $\left(\mathrm{CDCl}_{3}\right): \delta=27.63$ (s) ppm. ${ }^{13} \mathrm{C} \mathrm{NMR}\left(\mathrm{CDCl}_{3}\right): \delta=$ $152.3\left(\mathrm{~d},{ }^{4} J_{\mathrm{C}, \mathrm{P}}=2.3 \mathrm{~Hz}, \mathrm{ArC}\right), 143.8\left(\mathrm{~d},{ }^{3} J_{\mathrm{C}, \mathrm{P}}=15.9 \mathrm{~Hz}, \mathrm{ArC}\right)$, $124.8\left(\mathrm{~d},{ }^{1} J_{\mathrm{C}, \mathrm{P}}=177.1 \mathrm{~Hz}, \mathrm{ArC}\right), 122.4\left(\mathrm{~d},{ }^{2} J_{\mathrm{C}, \mathrm{P}}=10.9 \mathrm{~Hz}, \mathrm{ArC}\right)$, $77.2\left(\mathrm{~s},{ }^{3} J_{\mathrm{C}, \mathrm{Pt}}=31.7 \mathrm{~Hz}, \mathrm{ArCH}_{2} \mathrm{~N}\right), 59.9\left(\mathrm{~d},{ }^{2} J_{\mathrm{C}, \mathrm{P}}=5.5 \mathrm{~Hz}, \mathrm{CH}_{2} \mathrm{O}\right)$, $53.9\left[\mathrm{~s}, \mathrm{~N}\left(\mathrm{CH}_{3}\right)_{2}\right], 36.3\left[\mathrm{~d},{ }^{2} J_{\mathrm{C}, \mathrm{P}}=3.7 \mathrm{~Hz}, \mathrm{PN}\left(\mathrm{CH}_{3}\right)_{2}\right], 16.5\left(\mathrm{~d},{ }^{3} J_{\mathrm{C}, \mathrm{P}}\right.$ $=6.7 \mathrm{~Hz}, \mathrm{CH}_{3} \mathrm{CH}_{2} \mathrm{O}$ ) ppm. $\mathrm{C}_{16} \mathrm{H}_{29} \mathrm{BrN}_{3} \mathrm{O}_{2} \mathrm{PPt}$ (601.38): calcd. $\mathrm{C}$ 31.96, H 4.86, N 6.99; found C 31.85, H 4.67, N, 6.78.

Ethyl $P$-\{4-Chloroplatinum-1,3-bis[(dimethylamino)methyl]phenyl\}$\mathrm{N}, \mathrm{N}$-dimethylaminophosphinate (8): A solution of $7(0.77 \mathrm{~g}$, $1.28 \mathrm{mmol})$ in wet acetone $(20 \mathrm{~mL})$ was treated with $\mathrm{AgBF}_{4}(0.25 \mathrm{~g}$, $1.28 \mathrm{mmol}$ ) and stirred for $30 \mathrm{~min}$ at room temperature. The reaction mixture was filtered through a short pad of Celite and $\mathrm{NaCl}$ $(0.75 \mathrm{~g}, 12.80 \mathrm{mmol})$ was added to the filtrate. After stirring at room temperature for $2 \mathrm{~h}$, the solvent was removed and the crude product was dissolved in $\mathrm{CH}_{2} \mathrm{Cl}_{2}(20 \mathrm{~mL})$. Water $(20 \mathrm{~mL})$ was added and the $\mathrm{CH}_{2} \mathrm{Cl}_{2}$ phase was separated. The aqueous phase was extracted with $\mathrm{CH}_{2} \mathrm{Cl}_{2}(2 \times 20 \mathrm{~mL})$ and the combined organic 
fractions were dried with $\mathrm{MgSO}_{4}$. The mixture was filtered, the filtrate concentrated to $2 \mathrm{~mL}$ and pentane was added to precipitate the product as an off-white solid. Yield: $0.64 \mathrm{~g}(92 \%) .{ }^{1} \mathrm{H}$ NMR $\left(\mathrm{CDCl}_{3}\right): \delta=7.06\left(\mathrm{~d},{ }^{3} J_{\mathrm{H}, \mathrm{P}}=12.82 \mathrm{~Hz}, 2 \mathrm{H}, \mathrm{ArH}\right), 3.96\left(\mathrm{~s},{ }^{3} J_{\mathrm{H}, \mathrm{Pt}}\right.$ $\left.=46.88 \mathrm{~Hz}, 4 \mathrm{H}, \mathrm{CH}_{2} \mathrm{~N}\right), 3.92\left(\mathrm{~m}, \mathrm{CH}_{2} \mathrm{O}, 2 \mathrm{H}\right), 3.03\left[\mathrm{~s},{ }^{3} J_{\mathrm{H}, \mathrm{Pt}}=\right.$ $38.09 \mathrm{~Hz}, 12 \mathrm{H}, \mathrm{N}\left(\mathrm{CH}_{3}\right)_{2}$ ], $2.61\left[\mathrm{~d},{ }^{3} J_{\mathrm{HP}}=8.06 \mathrm{~Hz}, 6 \mathrm{H}, \mathrm{PN}-\right.$ $\left.\left(\mathrm{CH}_{3}\right)_{2}\right], 1.21\left(\mathrm{t},{ }^{3} J_{\mathrm{H}, \mathrm{H}}=6.96 \mathrm{~Hz}, 3 \mathrm{H}, \mathrm{CH}_{3} \mathrm{CH}_{2} \mathrm{O}\right) \mathrm{ppm} .{ }^{31} \mathrm{P} \mathrm{NMR}$ $\left(\mathrm{CDCl}_{3}\right): \delta=27.63$ (s) ppm. ${ }^{13} \mathrm{C} \mathrm{NMR}\left(\mathrm{CDCl}_{3}\right): \delta=152.9\left(\mathrm{~d},{ }^{4} J_{\mathrm{C}, \mathrm{P}}\right.$ $=2.3 \mathrm{~Hz}, \operatorname{ArC}), 144.0\left(\mathrm{~d},{ }^{3} J_{\mathrm{C}, \mathrm{P}}=15.2 \mathrm{~Hz}\right), 125.0\left(\mathrm{~d},{ }^{1} J_{\mathrm{C}, \mathrm{P}}=\right.$ $175.0 \mathrm{~Hz}, \operatorname{ArC}), 125.0\left(\mathrm{~d},{ }^{1} J_{\mathrm{C}, \mathrm{P}}=175.0 \mathrm{~Hz}, \operatorname{ArC}\right), 122.46\left(\mathrm{~d},{ }^{2} J_{\mathrm{C}, \mathrm{P}}\right.$ $\left.=10.4,{ }^{3} J_{\mathrm{C}, \mathrm{Pt}}=17.3 \mathrm{~Hz}, \operatorname{ArC}\right), 77.4\left(\mathrm{~s}, \mathrm{ArCH}_{2} \mathrm{~N}\right), 60.4\left(\mathrm{~d},{ }^{2} J_{\mathrm{C}, \mathrm{P}}=\right.$ $\left.6.1 \mathrm{~Hz}, \mathrm{CH}_{2} \mathrm{O}\right), 55.3\left[\mathrm{~s}, \mathrm{~N}\left(\mathrm{CH}_{3}\right)_{2}\right], 36.7\left[\mathrm{~d},{ }^{2} J_{\mathrm{C}, \mathrm{P}}=4.2 \mathrm{~Hz}\right.$, $\left.\mathrm{PN}\left(\mathrm{CH}_{3}\right)_{2}\right], \quad 16.6\left(\mathrm{~d},{ }^{3} J_{\mathrm{C}, \mathrm{P}}=6.7 \mathrm{~Hz}, \quad \mathrm{CH}_{3} \mathrm{CH}_{2} \mathrm{O}\right)$ ppm. $\mathrm{C}_{16} \mathrm{H}_{29} \mathrm{ClN}_{3} \mathrm{O}_{2} \mathrm{PPt}$ (556.93): calcd. C 34.51, H 5.25, N 7.54; found C 34.62, H 5.28, N 7.48 .

Ethyl 4-Nitrophenyl $\boldsymbol{P}$-\{4-Chloroplatinum-3,5-bis|(dimethylamino)methyl]phenyl\}phosphonate (2): A solution of compound 8 (200 mg, $3.59 \mathrm{mmol})$ in benzene $(20 \mathrm{~mL})$ was treated dropwise with anhydrous $\mathrm{HCl}\left(1 \mathrm{M}\right.$ in $\mathrm{Et}_{2} \mathrm{O}, 1.8 \mathrm{~mL}, 1.8 \mathrm{mmol}, 5$ equiv.) and afterwards the mixture was stirred for $3 \mathrm{~h}$. The formed turbid mixture was filtered under a $\mathrm{N}_{2}$ atmosphere, and a clear yellow solution was collected as filtrate. The filtrate was concentrated in vacuo to a yellowish solid. The solid residue was redissolved in benzene $(20 \mathrm{~mL})$ and dry $\mathrm{NEt}_{3}(36.3 \mathrm{mg}, 50 \mu \mathrm{L}, 3.59 \mathrm{mmol})$ was added to the mixture, followed by the dropwise addition of a solution of $p$ nitrophenol (50 mg, $3.59 \mathrm{mmol})$ in benzene $(20 \mathrm{~mL})$. Slowly, a turbid mixture was formed while the reaction mixture was stirred for one hour at room temperature. After filtration of the reaction mixture under a $\mathrm{N}_{2}$ atmosphere, a saturated $\mathrm{NaHCO}_{3}$ solution $(20 \mathrm{~mL})$ was added. The organic phase was separated and washed with a saturated $\mathrm{NaHCO}_{3}$ solution $(2 \times 20 \mathrm{~mL})$ followed by water $(20 \mathrm{~mL})$. The product-containing organic phase was dried with $\mathrm{MgSO}_{4}$, filtered, and concentrated to a pale yellow solid. Yield: $187 \mathrm{mg}(80 \%) .{ }^{1} \mathrm{H}$ NMR $\left(\mathrm{C}_{6} \mathrm{D}_{6}\right): \delta=7.74\left(\mathrm{~d},{ }^{3} J_{\mathrm{H}, \mathrm{H}}=9.16 \mathrm{~Hz}, 2\right.$ $\mathrm{H}, \mathrm{ArH}), 7.42\left(\mathrm{~d},{ }^{3} J_{\mathrm{H}, \mathrm{P}}=13.73 \mathrm{~Hz}, 2 \mathrm{H}, \mathrm{ArH}\right), 7.22\left(\mathrm{~d},{ }^{3} J_{\mathrm{H}, \mathrm{H}}=\right.$ $9.16 \mathrm{~Hz}, 2 \mathrm{H}, \mathrm{ArH}), 4.12\left(\mathrm{dt},{ }^{3} J_{\mathrm{H}, \mathrm{H}}=7.02,{ }^{3} J_{\mathrm{H}, \mathrm{P}}=15.57 \mathrm{~Hz}, 2 \mathrm{H}\right.$, $\left.\mathrm{CH}_{2} \mathrm{O}\right), 3.19\left(\mathrm{~s},{ }^{3} J_{\mathrm{H}, \mathrm{Pt}}=19.53 \mathrm{~Hz}, 4 \mathrm{H}, \mathrm{ArCH}_{2}\right), 2.59\left[\mathrm{~s},{ }^{3} J_{\mathrm{H}, \mathrm{Pt}}=\right.$ $\left.18.31 \mathrm{~Hz}, 12 \mathrm{H}, \mathrm{N}\left(\mathrm{CH}_{3}\right)_{2}\right], 1.10\left(\mathrm{t},{ }^{3} J_{\mathrm{H}, \mathrm{H}}=7.02 \mathrm{~Hz}, 3 \mathrm{H}\right.$, $\left.\mathrm{CH}_{3} \mathrm{CH}_{2} \mathrm{O}\right)$ ppm. ${ }^{31} \mathrm{P}$ NMR $\left(\mathrm{C}_{6} \mathrm{D}_{6}\right): \delta=20.6$ (s) ppm. ${ }^{13} \mathrm{C} \mathrm{NMR}$ $\left(\mathrm{C}_{6} \mathrm{D}_{6}\right): \delta=156.1\left(\mathrm{~d},{ }^{4} J_{\mathrm{C}, \mathrm{P}}=6.1 \mathrm{~Hz}, \mathrm{ArC}\right), 144.6\left(\mathrm{~d},{ }^{3} J_{\mathrm{C}, \mathrm{P}}=\right.$ 17.7 Hz, ArC), 144.6 (s, ArC), 127.1, 125.5 (s, ArC), 123.0 (d, ${ }^{2} J_{\mathrm{C}, \mathrm{P}}$ $=11.6 \mathrm{~Hz}, \operatorname{ArC}), 120.8\left(\mathrm{~d},{ }^{3} J_{\mathrm{C}, \mathrm{P}}=4.9 \mathrm{~Hz}, \operatorname{ArC}\right), 120.6\left(\mathrm{~d},{ }^{1} J_{\mathrm{C}, \mathrm{P}}=\right.$ 194.1 Hz, ArC), $76.9\left(\mathrm{~s},{ }^{3} J_{\mathrm{C}, \mathrm{Pt}}=31.1 \mathrm{~Hz}, \mathrm{ArCH}_{2} \mathrm{~N}\right), 62.7\left(\mathrm{~d},{ }^{2} J_{\mathrm{C}, \mathrm{P}}\right.$ $\left.=5.5 \mathrm{~Hz}, \mathrm{CH}_{2} \mathrm{O}\right), 53.8\left[\mathrm{~s}, \mathrm{~N}\left(\mathrm{CH}_{3}\right)_{2}\right], 16.3\left(\mathrm{~d},{ }^{3} J_{\mathrm{C}, \mathrm{P}}=6.1 \mathrm{~Hz}\right.$, $\mathrm{CH}_{3} \mathrm{CH}_{2} \mathrm{O}$ ) ppm. MS (MALDI-TOF, CSA): $\mathrm{m} / z=614.2[\mathrm{M}-\mathrm{Cl}]^{+}$, $420.1[\mathrm{M}-\mathrm{Cl}-\mathrm{Pt}]^{+}, 378.3[\mathrm{M}-\mathrm{Cl}-\mathrm{Pt}-\mathrm{OEt}]^{+} . \mathrm{C}_{20} \mathrm{H}_{27} \mathrm{ClN}_{3} \mathrm{O}_{5} \mathrm{PPt}$ (650.95): calcd. C 36.90, H 4.18, N 6.46; found C 37.01, H 4.26, N 6.37.

4-Bromopalladium \{3,5-bis[(dimethylamino)methyl]phenyl\}phosphonic Acid (3): A solution of 9 (121 mg, $0.24 \mathrm{mmol})$ in $\mathrm{CH}_{2} \mathrm{Cl}_{2}(6 \mathrm{~mL})$ was treated with of bromotrimethylsilane $(362 \mathrm{mg}, 312.2 \mu \mathrm{L}$, $2.36 \mathrm{mmol}, 10$ equiv.) and subsequently stirred for $4 \mathrm{~h}$ at room temperature. Dry $\mathrm{MeOH}(10 \mathrm{~mL})$ was added and the resulting yellow solution was stirred for $1 \mathrm{~h}$. All volatiles were evaporated in vacuo and the remaining residue was washed with dichloromethane $(2 \mathrm{~mL})$. The crude product was dissolved in a minimum amount of dry $\mathrm{MeOH}$. Slow addition of diethyl ether precipitated the product as an off-white solid. Yield: $96 \mathrm{mg}(89 \%) .{ }^{1} \mathrm{H}$ NMR $\left(\mathrm{D}_{2} \mathrm{O}\right): \delta=$ $7.05\left(\mathrm{~d},{ }^{3} J_{\mathrm{H}, \mathrm{P}}=12.6 \mathrm{~Hz}, 2 \mathrm{H}, \mathrm{ArH}\right), 3.96\left(\mathrm{~s}, \mathrm{CH}_{2}, 4 \mathrm{H}\right), 2.68(\mathrm{~s}$, $\left.\mathrm{NMe}_{2}, 12 \mathrm{H}\right)$ ppm. ${ }^{31} \mathrm{P}$ NMR $\left(\mathrm{D}_{2} \mathrm{O}\right): \delta=14.83$ (s) ppm. ${ }^{13} \mathrm{C} \mathrm{NMR}$ $\left(\mathrm{D}_{2} \mathrm{O}\right): \delta=156.4(\mathrm{~s}, \operatorname{ArC}), 145.9\left(\mathrm{~d},{ }^{3} J_{\mathrm{C}, \mathrm{P}}=15.4 \mathrm{~Hz}\right), 132.8\left(\mathrm{~d},{ }^{1} J_{\mathrm{C}, \mathrm{P}}\right.$ $=176.2 \mathrm{~Hz}, \operatorname{ArC}), 122.1\left(\mathrm{~d},{ }^{2} J_{\mathrm{C}, \mathrm{P}}=10.4 \mathrm{~Hz}, \operatorname{ArC}\right), 73.4\left(\mathrm{~s}, \mathrm{CH}_{2}\right)$, $52.2\left[\mathrm{~s}, \mathrm{~N}\left(\mathrm{CH}_{3}\right)_{2}\right] \mathrm{ppm}$.
4-Bromoplatinum \{3,5-bis|(dimethylamino)methyl]phenyl $\}$ phosphonic Acid (4): The same procedure as that for 3 was applied: 10 (100 mg, $0.17 \mathrm{mmol})$, bromotrimethylsilane $(252 \mathrm{mg}, 218 \mu \mathrm{L}, 1.66 \mathrm{mmol})$ in $\mathrm{CH}_{2} \mathrm{Cl}_{2}(5 \mathrm{~mL}), \mathrm{MeOH}(8 \mathrm{~mL})$, and dichloromethane $(2 \mathrm{~mL})$ were used. Yield: $85 \mathrm{mg}(94 \%) .{ }^{1} \mathrm{H}$ NMR $\left(\mathrm{D}_{2} \mathrm{O}\right): \delta=7.13\left(\mathrm{~d},{ }^{3} J_{\mathrm{H}, \mathrm{P}}=\right.$ $13.2 \mathrm{~Hz}, 2 \mathrm{H}, \mathrm{ArH}), 4.04\left(\mathrm{~s},{ }^{3} J_{\mathrm{H}, \mathrm{Pt}}=43.9 \mathrm{~Hz}, 4 \mathrm{H}, \mathrm{CH}_{2}\right), 2.89(\mathrm{~s}$, $\left.{ }^{3} J_{\mathrm{H}, \mathrm{Pt}}=36.2 \mathrm{~Hz}, 12 \mathrm{H}, \mathrm{NMe}_{2}\right) \mathrm{ppm} .{ }^{31} \mathrm{P} \mathrm{NMR}\left(\mathrm{D}_{2} \mathrm{O}\right): \delta=19.01$ (s) ppm. ${ }^{13} \mathrm{C}$ NMR $\left(\mathrm{D}_{2} \mathrm{O}\right): \delta=161.5(\mathrm{~s}, \mathrm{ArC}), 149.1\left(\mathrm{~d},{ }^{3} J_{\mathrm{C}, \mathrm{P}}=\right.$ $16.8 \mathrm{~Hz}, \operatorname{ArC}), 125.4\left(\mathrm{~d},{ }^{1} J_{\mathrm{C}, \mathrm{P}}=176.9 \mathrm{~Hz}, \operatorname{ArC}\right), 121.8\left(\mathrm{~d},{ }^{2} J_{\mathrm{C}, \mathrm{P}}=\right.$ $11.6 \mathrm{~Hz}, \mathrm{ArC}), 76.3\left(\mathrm{~s},{ }^{3} J_{\mathrm{C}, \mathrm{Pt}}=41.6 \mathrm{~Hz}, \mathrm{CH}_{2}\right), 54.4\left[\mathrm{~s}, \mathrm{~N}\left(\mathrm{CH}_{3}\right)_{2}\right]$ ppm.

Supporting Information (see footnote on the first page of this article): Crystallographic data of the crystal structures complexes 9 and 10.

\section{Acknowledgments}

The authors kindly wish to thank C. Versluis and Prof. A. J. R. Heck of the Biomolecular Mass Spectrometry group in the Department of Pharmaceutical Sciences at Utrecht University for measuring the ESI-MS spectra of various protein structures. This work was supported by the Council for Chemical Sciences of the Dutch organization for Scientific Research (CW-NWO) . The Unilever Research Laboratory at Vlaardingen in The Netherlands, is kindly acknowledged for the enzyme supply.

[1] a) J. Kraut, Ann. Rev. Biochem. 1977, 46, 331-358; b) P. E. Kolattukudy in Lipases, Elsevier, Amsterdam, 1984, 471-501; c) S. Ransac, Y. Gargouri, F. Marguet, G. Buono, C. Beglinger, P. Hildebrand, H. Lengsfeld, P. Hadvary, R. Verger, Methods Enzymol. 1997, 286, 190-231.

[2] a) O. V. Oskolkova, R. Saf, E. Zenzmaier, A. Hermetter, Chem. Phys. Lipids 2003, 125, 103-114; b) H. Schmidinger, R. BirnerGruenberger, G. Riesenhuber, R. Saf, H. Susani-Etzerodt, A. Hermetter, ChemBioChem 2005, 6, 1776-1781; c) G. Zandonella, P. Stadler, L. Haalck, F. Spener, F. Paltauf, A. Hermetter, Eur. J. Biochem. 1999, 262, 63-69.

[3] C. M. Salisbury, J. Ellman, ChemBio Chem 2006, 7, 1034-1037.

[4] a) N. Jessani, J. A. Young, S. L. Diaz, M. P. Patricelli, A. Varki, B. F. Cravatt, Angew. Chem. Int. Ed. 2005, 44, 2400-2403; b) A. E. Speers, B. F. Cravatt, ChemBioChem 2004, 5, 41-47; c) H. Schmidinger, H. Susani-Etzerodt, R. Birner-Gruenberger, A. Hermetter, ChemBioChem 2006, 7, 527-534.

[5] It should be noted that the hydrolytic sensitivity of the SerO$\mathrm{P}$ bond is dependent upon the nature of $\mathrm{R}^{1}$ (Figure 1). If for example $\mathrm{R}^{1}=p$-nitrophenyl, the SerO-P bond is easily hydrolyzed, thereby releasing the phosphonate group from the protein again (see ref. ${ }^{[7]}$ ). For the phosphonate inhibitors described in this paper with $\mathrm{R}^{1}=\mathrm{Et}$, no observable hydrolysis occurred for at least two weeks.

[6] a) C. A. Kruithof, G. Guillena, M. R. Egmond, G. van Koten in Book of Abstracts, First International Symposium on Bioorganometallic Chemistry, 18-20 July 2002, Paris, p. 104; b) C. A. Kruithof, M. A. Casado, G. Guillena, M. R. Egmond, A. van der Kerk-van Hoof， A. J. R. Heck， R. J. M. Klein Gebbink, G. van Koten, Chem. Eur. J. 2005, 11, 6869-6877.

[7] It should be stated that Reetz and co-workers were the first to publish the concept of site-specific introduction of metal-ligand systems into lipases via phosphonate inhibitors. Their examples, however, did not result in irreversible protein modification because of fast hydrolysis of the SerO-P bond (see also ref. ${ }^{[5]}$ ): see M. T. Reetz, M. Rentzsch, A. Pletsch, M. Maywald, Chimia 2002, 56, 721-723.

[8] a) J. Kjellgren, H. Sundén, K. J. Szabó, J. Am. Chem. Soc. 2005, 127, 1787-1796; b) J. T. Singleton, Tetrahedron 2003, 59, 1837-1857; c) H. P. Dijkstra, M. Q. Slagt, A. McDonald, C. A. 
Kruithof, R. Kreiter, A. M. Mills, M. Lutz, A. L. Spek, W. Klopper, G. P. M. van Klink, G. van Koten, Eur. J. Inorg. Chem. 2003, 830-838; d) H. P. Dijkstra, C. A. Kruithof, N. Ronde, R. van de Coevering, D. J. Ramón, D. Vogt, G. P. M. van Klink, G. van Koten, J. Org. Chem. 2003, 68, 675-685.

[9] a) M. Albrecht, M. Lutz, A. L. Spek, G. van Koten, Nature 2000, 406, 970-974; b) G. Guillena, K. M. Halkes, G. Rodríguez, G. D. Batema, G. van Koten, J. P. Kamerling, Org. Lett. 2003, 5, 2021-2024; c) D. Becatti, K. M. Halkes, G. Guillena, A. Carvalho de Souza, G. van Koten, J. P. Kamerling, ChemBioChem 2005, 6, 1196-1203.

[10] a) W. W. Gerhardt, A. J. Zucchero, J. N. Wilson, C. R. South, U. H. F. Bunz, M. Weck, Chem. Commun. 2006, 2141-2143; b) S.-E. Stiriba, M. Q. Slagt, H. Kautz, R. J. M. Klein Gebbink, R. Thomann, H. Frey, G. van Koten, Chem. Eur. J. 2004, 10, 1267-1273; c) H. J. van Manen, K. Nakashima, S. Shinkai, H. Kooijman, A. L. Spek, F. van Veggel, D. N. Reinhoudt, Eur. J. Inorg. Chem. 2000, 2533-2540; d) W. T. S. Huck, L. J. Prins, R. H. Fokkens, N. M. M. Nibbering, F. C. J. M. van Veggel, D. N. Reinhoudt, J. Am. Chem. Soc. 1998, 120, 6240-6246.

[11] L. Rutten, B. Wieczorek, J.-P. B. A. Mannie, H. P. Dijkstra, C. A. Kruithof, M. R. Egmond, M. Lutz, A. L. Spek, R. J. M. Klein Gebbink, G. van Koten, P. Gros, manuscript in preparation.

[12] a) K. K.-W. Lo, W.-K. Hui, C.-K. Chung, K. H.-K. Tsang, D. C.-M. Ng, N. Zhu, K.-K. Cheung, Coord. Chem. Rev. 2005, 249, 1434-1450; b) K. K.-W. Lo, W.-K. Hui, C.-K. Chung, K. H.-K. Tsang, T. K.-M. Lee, C.-K. Li, J. S.-Y. Lau, D. C.-M. Ng, Coord. Chem. Rev. 2006, 250, 1724-1736; c) M. Salmain, G. Jaouen, C. R. Chimie 2003, 6, 249-258.

[13] a) C. Letondor, T. R. Ward, ChemBio Chem 2006, 7, 1845-1852; b) T. Reetz, J. J.-P. Peyralans, A. Maichele, Y. Gu, M. Maywald, Chem. Commun. 2006, 4318-4320; c) D. Qi, C.-M. Tann, D. Haring, M. D. Distefano, Chem. Rev. 2001, 101, 3081-3111.

[14] Recently, we showed that this type of reactive phosphonate ester selectively inhibits serine hydrolases, see: H. P. Dijkstra, H. Sprong, B. N. H. Aerts, C. A. Kruithof, M. R. Egmond, R. J. M. Klein Gebbink, Org. Biolmol. Chem. 2008, 6, 523-531.

[15] L. D. Freedman, H. Tauber, G. O. Doak, H. J. Magnuson, J. Am. Chem. Soc. 1953, 75, 1379-1381.

[16] M. Q. Slagt, G. Rodríguez, M. P. Grutters, R. J. M. Klein Gebbink, W. Klopper, L. W. Jenneskens, M. Lutz, A. L. Spek, G. van Koten, Chem. Eur. J. 2004, 10, 1331-1344.

[17] G. Rodríguez, M. Albrecht, J. Schoenmaker, A. Ford, M. Lutz, A. L. Spek, G. van Koten, J. Am. Chem. Soc. 2002, 124, 51275138.
[18] M. Albrecht, G. Rodríguez, J. Schoenmaker, G. van Koten, Org. Lett. 2000, 2, 3461-3464.

[19] a) A. J. Canty, S. D. Fritsche, H. Jin, J. Patel, B. W. Skelton, A. H. White, Organometallics 1997, 16, 2175-2182; b) B. R. Steele, K. Vrieze, Trans. Met. Chem. 1977, 2, 140-144.

[20] D. M. Grove, G. van Koten, J. N. Louwen, L. G. Noltes, A. L. Spek, H. J. C. J. Ubbels, J. Am. Chem. Soc. 1982, 104, 66096616.

[21] a) M. L. M. Mannesse, G. H. de Haas, H. T. W. M. van der Heijden, M. R. Egmond, H. M. Verheij, Biochem. Soc. Trans. 1997, 25, 165-170; b) S. Longhi, M. L. M. Mannesse, H. M. Verheij, G. H. de Haas, M. R. Egmond, E. KnoopMouthuy, C. Cambillau, Protein Sci. 1997, 6, 275-286; c) J.-F. Cavalier, G. Buono, Acc. Chem. Res. 2000, 33, 579-588. Preliminary results of an X-ray structure of the NCN-pincer Pt complex phosphonate inhibitor 1 attached to cutinase N172K reveals the presence of the $S$ enantiomer in the active site. The commonly accepted mechanism for the inhibition reaction is the $\mathrm{S}_{\mathrm{N}} 2$ mechanism, which implicates that the reaction of $\mathbf{1}$ with cutinase has proceeded with the $R$ enantiomer as the most reactive isomer.

[22] Please note that the nonreactive enantiomer of $\mathbf{2}$ hydrolyzes to the same extent in both cuvettes and for this reason it does not account for changes in the absorbance level; the hydrolysis progresses equally in both cuvettes.

[23] a) The $85 \%$ inhibition of cutinase by the reactive enantiomer of 2 as determined from curve A (Figure 4), can also be explained by only considering the two competing reactions (Scheme 3 and Scheme 4). Whereas in the inhibition cuvette $100 \% p$-nitrophenolate release from 2 is a combined result of reactions 1 and 2, in the reference cuvette $15 \% p$-nitrophenolate release occurs as a results of reaction 2 only. Ideally, in the inhibition cuvette $100 \% p$-nitrophenolate release would result solely from reaction 1 (thus assuming reaction 2 does not occur), leading to the same increase in absorption as observed now (curve A). Obviously, this means that the $15 \%$ release in the reference cuvette is an overcompensation in the UV/Vis absorption, thus fully explaining the observed $85 \%$ inhibition rate of curve A. It should be noted that following this line of analysis does not tell anything about the amount of spontaneous hydrolysis of $\mathbf{2}$ in the inhibition cuvette. b) Rate was calculated by determining the slope of the $\ln \left([\mathrm{PnP}] /[\mathrm{PnP}]_{0}\right)$ vs. time plot. $R^{2}=0.9992$.

[24] E. L. Becker, Biochim. Biophys. Acta 1967, 147, 289-296.

Received: June 30, 2008 Published Online: August 25, 2008 